\title{
A Thematic Analysis of the Conceptual Framework of E-Learning in Higher Education
}

\author{
Mona Ghoreishi, ${ }^{1}$ Mohammad Ali Nadi, ${ }^{2,}$ Gholamreza Manshee, ${ }^{3}$ and Narges Saeedian ${ }^{4}$ \\ ${ }^{1}$ Educational Psychology, Department of Educational Psychology, Isfahan (Khorasgan) Branch, Islamic Azad University, Isfahan, Iran \\ ${ }^{2}$ Educational Science, Management, Department of Educational Science, Isfahan (Khorasgan) Branch, Islamic Azad University, Isfahan, Iran \\ ${ }^{3}$ Psychology, Department of Educational Psychology, Isfahan (Khorasgan) Branch, Islamic Azad University, Isfahan, Iran \\ ${ }^{4}$ Educational Management, Department of Management, Isfahan (Khorasgan) Branch, Islamic Azad University, Isfahan, Iran \\ "Corresponding author: Mohammad Ali Nadi, Educational Science, Management, Department of Educational Science, Isfahan (Khorasgan) Branch, Islamic Azad University, \\ Isfahan, Iran. E-mail: mnadi@khuisf.ac.ir
}

Received 2017 March 17; Accepted 2017 March 24.

\begin{abstract}
Background: E-learning is one of the new educational methods, integrating information and communication technology. It has managed to revolutionize teaching and learning methods by focusing on learners. In addition, many universities around the world are now educating students through designing and providing training programs and E-learning courses. The main objective of the current study was to present a conceptual framework of E-learning in higher education.

Methods: By reviewing various E-learning models and frameworks proposed during 2005-2016 by researchers or higher education institutes, we identified the common components with regard to 3 major criteria, ie, scientific basis of the model, international experience in higher education and universities of economic cooperation council, and availability of information. The gathered data were analyzed through inductive analysis and thematic network method, using Nvivo 8 software.

Results: Based on data analysis, 7 major themes, including individual characteristics, presentation practices, evaluation, infrastructure, content, media, and interaction, as well as 35 secondary themes, were introduced for E-learning in Iranian institutes of higher education.

Conclusions: Overall, the results of this study revealed the major and secondary themes of E-learning systems in the country, based on the extracted components and indicators in the E-learning model; also, the presented E-learning model was validated.
\end{abstract}

Keywords: E-Learning, Higher Education, Qualitative Approach, Thematic Analysis, Conceptual Framework

\section{Background}

Developments in information technology have led to the growth of online learning, as a new approach in education (1). E-learning involves learning through electronic media, including the Internet, extranet, audio and video tapes, television, and CDs. Clark and Mayer defined Elearning as the presentation of content through digital devices, such as computers and mobile phones in order to improve the process of learning (2). Today, E-learning has become a growing trend in learning, as well as an important strategy for promoting education in all countries (3).

According to the definition proposed in the literature (4), E-learning is a virtual learning environment where learners' interactions with their classmates, teachers, and training facilities happen through information and communication technology (ICT). The virtual environment is different from traditional environments, as in virtual settings, electronic communication technologies are used as a tool to support and improve the learning process.

E-learning provides many opportunities for the students, including virtual training. Educational reforms in developing countries, such as Iran, cannot occur outside the context of globalized knowledge and globalization. Elearning refers to the use of information and communication technologies to create and enrich learning experiences and to reflect globalized trends and globalization as part of the change and development in a community (5). Information explosion, communication development, changes in the system of governance, cultural evolution, and interconnectedness of global communities have led to fundamental changes in perspectives about and need for higher education (6).

The major consequence of such changes is the challenges of higher education in this century (7). These challenges are as follows: (1) consistency between dramatic changes in the global education system, rate of knowledge production, and need for continuous training; (2) the growing demand for university entrance to achieve the required information literacy with respect to the phenomenon of globalization; and (3) the need to meet the growing demands for educational strategies, focusing on educational justice, user-orientation, and attraction of talented domestic and foreign students. 
There are different ways to overcome the mentioned challenges. However, it should be noted that E-learning is considered an emerging phenomenon in many countries, including Iran, and it has not been yet practically or comprehensively used as expected. Regardless of the associated benefits and opportunities, this type of learning, similar to any other emerging phenomenon, has been associated with some uncertainties and challenges in developing countries (8).

In countries such as Iran where on one hand, the youth's willingness to continue university studies and scientific progress has increased, and on the other hand, knowledge has created added value (due to recent global developments and information age), it seems that such fundamental challenges can be overcome only through Elearning. Therefore, it is necessary to evaluate and implement E-learning systems in form of a conceptual framework. Accordingly, the research question can be stated as follows: What are the components of the E-learning model?

\section{Methods}

With respect to the objective of the study, ie, extracting the components of E-learning models, a qualitative design was applied. In order to develop a conceptual framework of E-learning model, first, the literature, related to the models and frameworks introduced by various researchers, was reviewed. Then, the main components of Elearning were identified according to 3 major criteria: (1) scientific basis of the model; (2) international experience in higher education and universities of the economic cooperation council; and (3) availability of information. Afterwards, the components and factors affecting E-learning were extracted. For the analysis of the conceptual framework, thematic analysis was used, based on the inductive approach.

\subsection{E-Learning Models and the Conceptual Framework}

So far, many researchers, universities, and institutes of higher education have introduced the dimensions and underlying constituents of E-learning framework by providing theoretical models and frameworks. In order to develop a conceptual framework of E-learning model, first, the literature on the models and frameworks proposed by various researchers, was reviewed. Then, the main components of E-learning were identified according to the discussed criteria. Some of the mentioned models are summarized in Tables 1 and 2.

Thematic analysis is one of the efficient methods of qualitative analysis (30). It is also one of the common forms of qualitative analysis. Boyatzis introduced it as a specific method and instrument applied in different methods (31). Ryan and Bernard also introduced the coding of themes as a prerequisite to the main qualitative analysis rather than a unique and specific method (32). However, according to Brown and Clarke, thematic analysis with the advantage of flexibility should be taken into account as a particular method (33).

Thematic analysis is a method for identifying, analyzing, and reporting patterns in qualitative data. This method is a process for analyzing texts and transforming diverse data into rich and detailed information. In addition, thematic analysis is a method used to both state and explain a fact. It represents important details about the data and research question and to some extent indicates the meanings and concepts in a set of data.

Overall, thematic analysis is a repetitive and distinctive method of text assessment, which according to researchers presents a particular perception and analysis of the research question (34). Therefore, in the current study performed in 2016, thematic analysis was used to identify and extract the components of E-learning.

In order to record the components, they were entered into Microsoft Word software and then entered in Nvivo 8 software for coding analysis. If parts of the same theme were encountered in the analysis, the same previous codes were used. The process of identifying the codes was in form of back and forth. First, through reviewing the literature, the primary and general concepts of E-learning were extracted. Then, by reviewing the literature, new and detailed concepts were identified. The identified codes were categorized and combined, based on conceptual similarity; then, they were specified in the software in form of free nodes.

Finally, the researcher identified the concepts, based on his perception and understanding of the issue. The themes were classified as main and secondary, according to the common concepts. The main and secondary themes were displayed in a tree node in Nvivo 8. This process continued until all the concepts were allocated to the related themes. After classifying all the secondary themes and categorizing them under the rubric of the main themes, the mentioned process was revised several times. In fact, the secondary and main themes were refined several times, and some were separated, combined, deleted, or added. This process continued until the outline of the thematic network was obtained. The thematic network in this study consisted of 7 main themes and 35 secondary themes.

\subsection{The Main Stages of Research Implementation}

In this study, in order to identify the E-learning model, inductive analysis and thematic network method were 
Table 1. E-Learning Models and Frameworks (Foreign Studies)

\begin{tabular}{|c|c|}
\hline Presenter of the Framework & Main Components \\
\hline Odanak $(9)$ & $\begin{array}{l}\text { Proper planning for the preparation of E-learning programs, support programs, adoption of optimal practices, education, cooperation and coordination, maximization of } \\
\text { the use of learning management systems, curriculum development, and content development }\end{array}$ \\
\hline Frimpon (10) & Students, teachers, technology, and institutes \\
\hline Yasiri et al. (11) & $\begin{array}{l}\text { Learner's characteristics, instructor's characteristics, quality of services and organization, quality system and structure, information quality, and the course and extrinsic } \\
\text { motivations }\end{array}$ \\
\hline Li and Lau (12) & Instructor's characteristics, educational content, and user's satisfaction \\
\hline Holm (13) & Quality of the system, quality of services, quality of content, issues related to the students' views, faculty members' attitude, and support \\
\hline E-learning quality model (14) & $\begin{array}{l}\text { Content (materials), structure of the virtual environment, interactions, collaboration and communication, student evaluation, flexibility, adaptability and compatibility, } \\
\text { support for the students and the staff, experience, employees' qualifications and experiences, insight and organizational leadership, resource allocation, and generalities } \\
\text { and aspects of the process }\end{array}$ \\
\hline Virtual Training Center of the University of Illinois (15) & $\begin{array}{l}\text { Educational design, communication, interaction and cooperation assessment, evaluation of students, resources and services, comprehensive support, web design, and } \\
\text { course evaluation }\end{array}$ \\
\hline UIf $(16)$, General framework of E-learning & Provision of the infrastructure, technical standards, content, educational issues, and school development \\
\hline Selim (17), Based on the learners' perceptions & Teacher's characteristics, learner's characteristics, technology, and support \\
\hline Fresen (18) & School-related factors, technology-related factors, teacher-related factors, educational design, and training factors \\
\hline Khan (19), General framework of E-learning & Administrative, managerial, and technological affairs, educational, training, and moral affairs, design of intermediaries, resource support, and evaluation \\
\hline
\end{tabular}

Table 2. E-Learning Models and Frameworks (Domestic Studies)

\begin{tabular}{|c|c|}
\hline Presenter of the Framework & Main Components \\
\hline Baghery Majd et al. (20) & $\begin{array}{l}\text { Program and resource management, learner centeredness, flexibility, communication tools, evaluation, learning strategies and methods, organization, design styles, objective analysis, media } \\
\text { analysis, content analysis, learner analysis, principles, technology, evaluation tools, cyber quality, time management, workforce management, virtual thoughts and ethics, educational priorities, } \\
\text { and virtual experiences }\end{array}$ \\
\hline Anarinejad and Mohammadi (21) & Organization, management, technology related to education, design of the presentation environment, support services, evaluation, and ethical considerations \\
\hline Rostami Nejad et al. (22) & E-learning satisfaction, control center, computer reliance, test anxiety and learner's independence, E-learning, time management, and self-regulation \\
\hline Sanayei and Salimian (23) & External factors (including social impact, system quality, facilitating conditions, perceived benefits, and perceived ease of use) and internal factors (motivation and self-efficacy) \\
\hline Mousavi et al. (24) & Method and content, accessibility and attitude, culture, encouragement, and infrastructure \\
\hline Elahi et al. (25) & Individual components and individual characteristics, environmental factors and infrastructure, educational content, and educational media \\
\hline Saghafi et al. (26) & Resource management and strategy, customers, organizational processes, learning, and development \\
\hline Yaghoubi et al. (27) & $\begin{array}{l}\text { Individual factors (self-esteem, participation and creativity, IT skills, motivation and attitude, and virtualization capabilities) and variables related to the characteristics of faculty members } \\
\text { (management and promotion, virtual presence and interactions, E-skills and commitment, supply of the interactive environment, positive attitude, and facilitation) }\end{array}$ \\
\hline Safavi (28) & $\begin{array}{l}\text { Organizational strategy, development plans and budget, technical and organizational infrastructure, quality-assurance measures, training of the personnel, educational content production, } \\
\text { announcement, acceptance and management, evaluation systems and progress measurement, education, counseling and monitoring of the criteria, student and teacher support systems, help } \\
\text { and technical support of the system and users, and guidance and directions for the students and teachers at the onset of the course }\end{array}$ \\
\hline Jafari and Saeedian (29) & oject-based learning, interest and skills in modern learning, innovative learning, student-centered learning, and research-based teaching \\
\hline
\end{tabular}

used, based on the literature and E-learning models. In general, the process of thematic analysis in this study consisted of 3 phases:

1. Description of the content: (A) to understand the content (writing the initial ideas); (B) to create the initial codes, ie, coding; and $(C)$ to investigate and recognize the themes (theme extraction and matching the codes or templates of the themes).

2. Interpretation and explanation: (A) outlining the thematic network; and (B) analysis of the thematic network.

3. Synthesis and integration: (A) to formulate the conceptual framework.

The related themes and frequencies are presented in Table 3.

As shown in the Table, the major themes of the Elearning framework include the learner's characteristics, content, media, interaction, presentation practices, evalu- ation, and infrastructure. In order to clarify the distinctive features of the current research using the most relevant studies, a comparison is presented in Table 4, based on the E-learning content.

\section{Results}

In the first stage, we identified and extracted the themes by examining previous studies, E-learning models, and some criteria and indicators introduced by different researchers, experts, and successful international universities, implementing this type of education. The themes were extracted according to 3 criteria: (1) scientific basis of the model, (2) international experience in higher education and universities of the economic cooperation council, and (3) availability of information.

According to the Table a comprehensive model of Elearning was presented, considering the themes. One lim- 
Table 4. Comparison of Models in the E-Learning Environment

\begin{tabular}{|c|c|c|c|c|c|c|c|c|}
\hline Organized content & $\begin{array}{l}\text { Individual } \\
\text { characteristics } \\
\text { of the learner }\end{array}$ & $\begin{array}{l}\text { Educational } \\
\text { content }\end{array}$ & $\begin{array}{l}\text { Educational } \\
\text { media }\end{array}$ & Interaction & $\begin{array}{l}\text { Measurement } \\
\text { method }\end{array}$ & $\begin{array}{l}\text { Presentation } \\
\text { (oral) }\end{array}$ & $\begin{array}{c}\text { Technology } \\
\text { infrastructure }\end{array}$ & $\begin{array}{c}\text { Cultural and } \\
\text { educational } \\
\text { infrastructures }\end{array}$ \\
\hline \multicolumn{9}{|l|}{ Model } \\
\hline $\begin{array}{l}\text { Reference model (International } \\
\text { Institute For Education Planning, 2013) }\end{array}$ & * & * & * & * & & * & * & \\
\hline The education system (Alis, 2009) & & * & & & & * & * & \\
\hline $\begin{array}{l}\text { The combined model of virtual } \\
\text { university (University of Illinois, 2007) }\end{array}$ & & * & * & * & & * & * & \\
\hline E-learning design model (Fresen, 2005) & * & * & & * & & & * & \\
\hline $\begin{array}{l}\text { Virtual university model emphasizing } \\
\text { on intelligent assessment (European } \\
\text { Commission, 2003) }\end{array}$ & * & * & & * & & * & * & \\
\hline $\begin{array}{l}\text { General framework for E-learning } \\
\text { (Khan, 2005) }\end{array}$ & * & * & * & * & & * & * & \\
\hline $\begin{array}{l}\text { E-learning model (the present study) } \\
\text { (2016) }\end{array}$ & * & * & * & * & * & * & * & * \\
\hline
\end{tabular}

itation was that the present study was conducted at a certain time in a certain place; therefore, the results should be generalized with caution.

\subsection{Description of the Main Themes}

In this article, E-learning in higher education was studied given its significance, and an E-learning conceptual framework was introduced. Seven main themes were discussed and introduced, which are as follows:

Characteristics of the learner: It is one of the factors, which has always led to disputes in the discussion of learning. Some researchers argue that this factor plays a marginal role in learning (35), whereas others designate a major role to it $(36,37)$.

Educational content: According to Lee and Hwang, learning content is a critical factor in the success and direction of learning, leading to the learner's satisfaction (38).

Media: Educational media is a tool to teach the learner. In many communities, as the demand for educated people increases, traditional methods fail to meet the learners' needs. Also, developments in information technology have contributed to the growth of online education as one of the important training practices in today's world (25).

Interaction: The key in E-learning systems is student-tostudent interaction, teacher-student interaction, and participation in learning, which is an outcome of these interactions. These systems benefit from tools such as E-mail, boards, writing boards, and chat rooms to provide such interactions (39).

Presentation practices: In most Eastern countries, oral traditions play a large role in establishing and maintaining interaction; therefore, they must be considered in the design of E-learning opportunities. In cultures with high verbal power, textual tools, such as chats and forums, are not highly welcomed. Therefore, it is better to simultaneously use non-textual tools such as chat rooms (speech), along with textual ones in presenting the content (5).

Evaluation: As mentioned above, education, especially higher education, is most often considered a necessity and a bridge to achieve a higher social status. As educational opportunities are often limited, serious competition among students is encouraged and promoted as soon as entering school. In addition, exams focus on the students' memory capacity rather than their critical thinking or problem-solving skills. However, for real learning, evaluation should be based on critical thinking and problemsolving.

Infrastructure: In general, to set up and use ICT in education, we need strong infrastructures. In fact, design and implementation of E-learning environments in vacuum, without considering the cultural roots, should not be attempted. In other words, the applied technologies (such as learning management systems), production and use of electronic content, and even interaction with others are a function of culture and cultural aspects of education. Accordingly, educational production, which is quite successful in one culture, may not succeed in another cultural context (40).

The outlined thematic network consists of 7 main themes and 35 secondary themes.

\subsection{Validation of the Conceptual Framework}

To assess the thematic analyses in this study, first, the independent coders were used as a common process for evaluating and controlling the quality of thematic analysis. In the positivist approach to qualitative studies, thematic analysis is similar to the statistical calculation of internal reliability in quantitative content analysis or structured observations. 


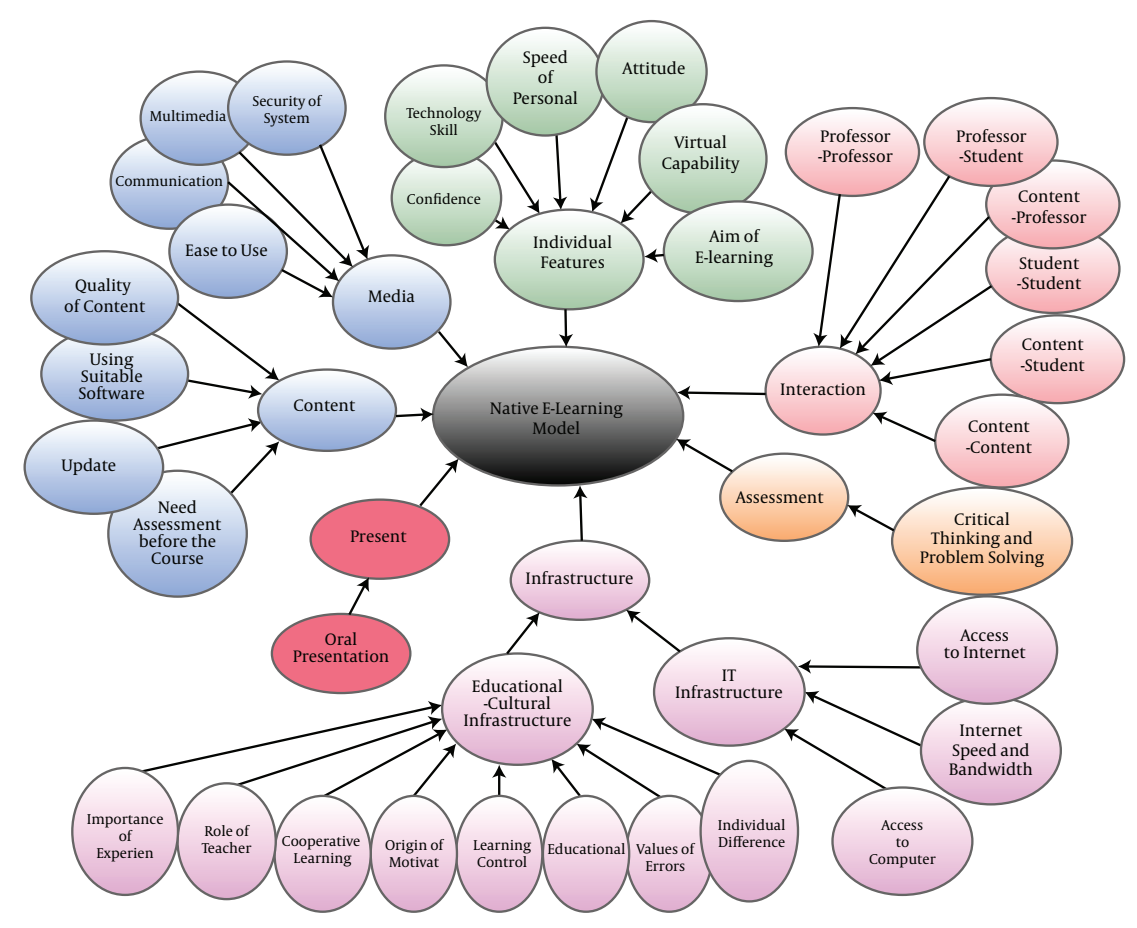

Figure 1. Outline of the Thematic Network

The purpose of independent coding, in most cases, is not to demonstrate the validity or reliability of thematic analysis, but to help researchers think critically about the structure of the proposed contents and decisions about coding. This issue becomes more prominent when the analyst's assumptions and expectations encourage attention to certain parts of the data or disregard some other parts. Therefore, independent coding is commonly applied as a way to avoid the analyst's lack of objectivity (34).

To assess the validity of the present research, while comprehensive, organizational, and main contents were selected and confirmed by reviewing the literature (including the theoretical frameworks, research objectives, and resources), expert opinions and guidelines were considered, as well. In the first stage, the themes were extracted by the researcher, and in the second stage, the themes were extracted and identified by specialists. By comparing the 2 stages and considering the agreement between the 2 encoding stages, the reliability coefficient was calculated. The Holsti's method was used for this purpose. The formula is as follows:

$\mathrm{PAO}=2 \mathrm{M} /\left(\mathrm{n}_{1}+\mathrm{n}_{2}\right)=2.232 / 232+286=0.895$

where PAO is the percentage of the agreement observed (reliability coefficient), $M$ denotes the number of consensus decisions in coding, $\mathrm{n}_{1}$ is the number of units encoded in the first stage, and $n_{2}$ is the number of units encoded in the second stage. The values range between 0 (no agreement) and 1 (perfect agreement). The calculation results show that the research findings have high reliability.

\section{Discussion and Conclusion}

The integrated measures to achieve the educational goals include the use of media, such as computers, use of psychological learning theories, and combining the results in general. Review of scientific literature and studies related to educational technology indicates that knowledge has the most significant relationship with the teaching/learning process. In fact, by applying different scientific achievements, it aims to improve the general outcomes of teaching and learning (12).

On the other hand, an E-learning environment provides a strong tool for learners, enabling them to be involved in new learning situations in a cognitive effort. It also allows them to monitor their learning and consider their options (17). In addition, features of E-learning, such as flexibility, learner-orientation, constant accessibility, high interactivity, improvement of students' motivation, and accessibility of information resources through the Internet have caused E-learning courses to be a major part of higher education. 
In general, it can be stated that information technology provides an excellent opportunity to change or reshape teaching and learning activities in higher education and facilitates the design of modern scientific environments, which was not possible before. In this study, given the significance of E-learning and some challenges in the field, the need to design and provide a conceptual framework for higher education was discussed and investigated. Afterwards, the most important model was introduced.

In order to present a conceptual design for E-learning, previous studies, models, and frameworks, proposed by different researchers, experts, and some universities in the field of E-learning were first examined, and the main and secondary themes of E-learning were identified. Then, by using the views of experts and scholars, the conceptual framework was validated, and the thematic network was drawn in form of 7 main themes (ie, individual characteristics, presentation practices, evaluation, infrastructure, content, media, and interaction) and 35 secondary themes.

The main finding of this research is that universities and institutes of higher education in Iran, offering E-learning programs, can use the proposed conceptual framework in E-learning. One of the advantages of this framework is its comprehensiveness, involving all elements of E-learning systems. The current study also compared the identified themes and aligned them accordingly.

We compared the identified content with previous research. In this regard, Nichols (41) introduced some themes including the student's past educational performance, demographics, aim of E-learning, familiarity with computers, and cooperative learning. Also, SánchezFranco (42) mentioned the aim of E-learning, attitude, ease of use, and cooperative learning, while Lim and Lee (1) introduced demographics, updated information and content, information and content quality, and need assessment before the course.

In the present study, the following factors were included: student's past performance, demographics, Elearning objectives, virtual capability, attitude, familiarity with computers, confidence, technology skills, speed of personal learning, ease of use, communication, use of multimedia, system security, information and content update, information and content quality, need assessment before the course, interactions, suitable software and content organization, Internet speed and band width, motivation, individual differences, cooperative learning, teacher's role, experimental importance, educational approach, assessment based on critical thinking and problem-solving, interactions among university teachers and students, interactions among learners, interactions among university teachers, interaction between content and content, inter- action between content and students, interactions among university teachers and students, use of forums as a tool, specifications of the teacher's plan, and use of chat environments and online classes.

Compared to previous studies, the most important advantage of the proposed model was the system comprehensiveness. This model consisted of 7 major themes, ie, individual characteristics, presentation practices, evaluation, infrastructure, content, media, and interaction. Also, 35 secondary themes for E-learning in Iranian institutes of higher education were introduced, which were extracted based on expert opinion and the literature and were considered as the input of the expert system.

As mentioned earlier, a comprehensive model of Elearning was presented considering the themes. The major limitation was that this study was conducted at a certain time in a certain place. Therefore, the results should be generalized with caution. Finally, it should be mentioned that this study does not claim to have considered all E-learning themes. However, we tried to pave the way for researchers interested in E-learning with a comprehensive view of the phenomenon.

\section{Acknowledgments}

The authors would like to thank the editors and the 3 anonymous reviewers for their constructive review.

\section{Footnotes}

Authors' Contribution: Study concept, Mohammad Ali Nadi; Gholamreza Manshee; and Narges Saeedian, Analysis and interpretation of data, drafting of the manuscript, and critical revision of the manuscript for important intellectual content, Mona Ghoreishi.

Conflicts of interests: None declared.

\section{References}

1. Lim $H$, Lee $S$, Nam K. Validating E-learning factors affecting training effectiveness. Int J Info Manag. 2007;27(1):22-35. doi: 10.1016/j.ijinfomgt.2006.08.002.

2. Clark RC, Mayer RE. E-learning and the science of instruction: Proven guidelines for consumers and designers of multimedia learning. fourth ed. John Wiley \& Sons; 2016.

3. Chu $\mathrm{H}$, Liao $\mathrm{M}$, Chen $\mathrm{T}$, Lin $\mathrm{C}$, Chen $\mathrm{Y}$. Learning case adaptation for problem-oriented e-learning on mathematics teaching for students with mild disabilities. Expert Syst Appl. 2011;38(3):1269-81. doi: 10.1016/j.eswa.2010.06.037.

4. Alavi M, Leidner DE. Research commentary: Technology-mediated learning-a call for greater depth and breadth of research. Info Syst Res. 2001;12(1):1-10. doi:10.1287/isre.12.1.1.9720.

5. Masoumi D, Lindstrom B. Foundations of cultural design in e-learning. Int J Internet Ent Manage. 2009;6(2):124-42. doi: 10.1504/ijiem.2009.023926. 
6. Wang Y. Assessment of learner satisfaction with asynchronous electronic learning systems. Info Manage. 2003;41(1):75-86. doi: 10.1016/s0378-7206(03)00028-4.

7. Johnson RD, Hornik S, Salas E. An empirical examination of factors contributing to the creation of successful e-learning environments. Int J Hum Comput Stud. 2008;66(5):356-69. doi: 10.1016/j.ijhcs.2007.11.003.

8. Ghaedi B, Askari MA, Attaran M, editors. Evaluating virtual curriculum in computer engineering [In Persian]. Proceedings of second international conference on E-learning. 2007; Zahedan. pp. 12-23.

9. Odunaike S, Olugbara O, Ojo S. E-learning implementation critical success factors. innovation. 2013;3(4).

10. Frimpon MF. A re-structuring of the critical success factors for elearning deployment. Am Int J Contemp Rese. 2012;2(3):115-27.

11. Bhuasiri W, Xaymoungkhoun O, Zo H, Rho JJ, Ciganek AP. Critical success factors for e-learning in developing countries: A comparative analysis between ICT experts and faculty. Comput Educ. 2012;58(2):843-55. doi: 10.1016/j.compedu.2011.10.010.

12. Li Q, Lau RWH, Wah BW, Ashman H, Leung EWC, Li F, et al. Guest editors' introduction: Emerging internet technologies for e-learning. IEEE Int Comput. 2009;13(4):11-7. doi: 10.1109/mic.2009.83.

13. United States Distance Learning Association. USDLA best practices in distance learning programming for online distance learning 2009. Available from: http://www.usdla.org.

14. North American Council for Online Learning (NACOL). National standards of quality for online courses 2008. Available from: http://www. nacol.org.

15. Illinois Online Network (ION) University of Illinois . A Tool to Assist in the Design Redesign.And/or Evaluation of Online Courses 2007. Available from: http://www.ion.illinois.edu.

16. Ehlers U, Pawlowski JM. Handbook on quality and standardisation in e-learning. Springer Science \& Business Media; 2006.

17. Selim HM. Critical success factors for e-learning acceptance: Confirmatory factor models. Comput Educ. 2007;49(2):396-413. doi: 10.1016/j.compedu.2005.09.004.

18. Fresen JW. Quality assurance practice in online (web-supported) learning in higher education: An exploratory study:. University of Pretoria; 2005.

19. Khan B. Managing e-learning: Design, delivery, implementation, and evaluation. George Washington University: USA; 2005.

20. Baghery Majd R, Seyed Abbas M, Alizadeh Y, Shahi S. Survey and design pedagogical model in virtual higher education system [In Persian].J InfoCommun Technol Educ. 2013;4(3):127-44.

21. Anarinejad A, Mohammadi M. The practical indicators for evaluation of e-learning in higher education in Iran [In Persian]. Interdiscip J Virtual Learn Med Sci (IJVLMS). 2014;5(1):11-25.

22. Rostami Nejad MA, Mozini N, Delavar A, Norozi D. Validation of a tool for predicting Iranian engineering student success in e-Learning, Iranian [In Persian]. Journal of Engineering. 2013;15(57):113-32.

23. Rastgarpour H, Georgizade S. Assessing the effectiveness of e-learning courses at Tarbiat Modarres University from the perspective of users [In Persian]. Quar J Info Commun Technol Educ Sci. 2012;2(3):5-30.

24. Masoumi D. In: E-learning in Iran: A breakthrough to ICT-based initiatives in an educational system. U. Demiray, editor. Eskisehir-Turkey: Anadolu University; 2010. pp. 229-51.E-learning practices: Cases on challenges facing e-learning and national development.

25. Elahi S, Kanaani F, Shayan A. Designing a framework for effective factors on virtual students' tendency to the electronic learning and its assessment [In Persian]. Quart J Res Plann Higher Educ. 2011;17(2):5980.

26. Saghafi F, Mir Saeed Ghazi T, Kharrat M, editors. Key factors for the success of deployment of e-learning in educational institutions [In Persian]. International Conference on e-learning and Technology. 2011; pp.1-7.

27. Yaghoubi J, editor. A survey of the attitude of students in agricultural extension and education to e-learning. Proceedings of Second Inter- national Conference on E-learning [In Persian]. 2008; Zahedan. pp. 64-9.

28. Safavi AA, Mohammadi M, editors. Validating and monitoring elearning courses in Iran [In Persian]. Second Conference on Elearning Zahedan. 2008; pp. 215-27.

29. Jafari P, Saeidian N. A Study of pedagogical aspects of virtual university in order to present appropriate model [In Persian]. JSR. 2007;1(12):1-26.

30. Holloway I, Todres L. The status of method: Flexibility, consistency and coherence. Qual Res. 2003;3(3):345-57. doi: $10.1177 / 1468794103033004$.

31. Boyatzis RE. Transforming qualitative information: Thematic analysis and code development. sage; 1998.

32. Ryan GW, Bernard HR. In: Handbook of qualitative research. Denzin NK, Lincoln YS, editors. ; 2000. Data management and analysis methods.

33. Braun V, Clarke V. Using thematic analysis in psychology. Qual Res Psychol. 2006;3(2):77-101. doi: 10.1191/1478088706qp063oa.

34. King N, Horrocks C. Interviews in qualitative research. Sage; 2010.

35. Pituch KA, Lee Y. The influence of system characteristics on e-learning use. Comput Educ. 2006;47(2):222-44. doi: 10.1016/j.compedu.2004.10.007.

36. Hong K. Relationships between students' and instructional variables with satisfaction and learning from a Web-based course. Int Higher Educ. 2002;5(3):267-81. doi: 10.1016/s1096-7516(02)00105-7.

37. Thurmond VA, Wambach K, Connors HR, Frey BB. Evaluation of student satisfaction: Determining the impact of a web-based environment by controlling for student characteristics. Am J Dist Educ. 2002;16(3):169-90. doi:10.1207/s15389286ajde1603_4.

38. Liaw S, Huang $\mathrm{H}$, Chen G. Surveying instructor and learner attitudes toward e-learning. Comput Educ. 2007;49(4):1066-80. doi: 10.1016/j.compedu.2006.01.001.

39. Zamapour A, Mirzabeygi MA. Investigating the factors affecting academic performance of e-learning learner in higher education and providing a successful model based on the learner's perspective [In Persian]. J Curriculum Stud. 2010;4(16):164-30.

40. Masoumi D, Lindström B. E-learning as a cultural artifact: Anempirical study of Iranian Virtual Institutions. Paper presented at the CulturalAttitudes Towards Technology and Communication Conference (CATAC 2012),Arhus, Danmark North American Council for Online Learning (NACOL), National Standards of Quality for Online Courses; 2012. Available from: http://www.nacol.org.

41. Nichols AJ. An empirical assessment of attitude toward computers, motivation, perceived satisfaction from the e-learning system, and previous academic performance and their contribution to persistence of college student athletes enrolled in e-learning courses. Nova Southeastern University; 2008.

42. Sánchez-Franco MJ, Martínez-López FJ, Martín-Velicia FA. Exploring the impact of individualism and uncertainty avoidance in Web-based electronic learning: An empirical analysis in European higher education. Comput Educ. 2009;52(3):588-98. doi: 10.1016/j.compedu.2008.11.006.

43. Slade SE. Employer provided optional e-training: Employing Gilbert's Behavioral Engineering Model in analyzing environmental and individual factors impacting participation [PhD Thesis]. Capella University; 2008.

44. Schecter B. Design and evaluation of museum websites for adolescents; A developmental approach. 2005 :24-32.

45. Lee J, Hong NL, Ling NL. An analysis of students' preparation for the virtual learning environment. Int Higher Educ. 2001;4(3-4):231-42. doi: 10.1016/s1096-7516(01)00063-x.

46. Ribble MS, Bailey GD. Web design and maintenanceApproach: A Rubric for creating Educational Websites 2006. Available from: www. educ.ksu.edugoality.

47. Porter LR. Developing an online curriculum: Technologies and tech- 
niques:. IGI Global; 2004.

48. Moallem M. An interactive online course: A collaborative design model. Educ Technol Res Dev. 2003;51(4):85-103. doi: 10.1007/bf02504545.

49. Hansen MM. Versatile, immersive, creative and dynamic virtual 3-D healthcare learning environments: a review of the literature.J Med Internet Res. 2008;10(3):e26. doi: 10.2196/jmir.1051. [PubMed: 18762473].

50. Ibrahimzadeh I, Zandi B, Alipour A, Zare H, Yazdani F. The kinds of e-learning and different forms of interaction on it [In Persion]. Interdiscip J Virtual Learn Med Sci. 2010;1(1):11-22.

51. Grayson DR, Anderson T. E-learning in the 21st century: (theoretical and practical) [In Persian]. trans, 1st ed. Tehran: Science and Technology; 2003.

52. Moallem M. Accommodating individual differences in the design of online learning environments. J Res Technol Educ. 2007;40(2):217-45. doi:10.1080/15391523.2007.10782506.

53. Pettenati MC, Cigognini E, Mangione J, Guerin E. Using social software for personal knowledge management in formal online learning. Turk- ish Online J Dist Educ. 2007;8(3)

54. Govindasamy T. Successful implementation of e-Learning. Int Higher Educ. 2001;4(3-4):287-99. doi:10.1016/s1096-7516(01)00071-9.

55. Benson Soong MH, Chuan Chan H, Chai Chua, Fong Loh K. Critical success factors for on-line course resources. Comput Educ. 2001;36(2):10120. doi: 10.1016/s0360-1315(00)00044-0.

56. Sfard A. On Two Metaphors for Learning and the Dangers of Choosing Just One. Educl Res. 1998;27(2):4-13. doi:10.3102/0013189x027002004.

57. Reeves TC, Reeves PM. Web-based instruction. ; 1997. pp. 5966.Effective dimensions of interactive learning on the World Wide Web.

58. Henderson L. Instructional design of interactive multimedia: A cultural critique. Educ Technol Res Dev. 1996;44(4):85-104. doi: 10.1007/bf02299823.

59. Masoumi D, Masoumi B. Cultural and educational infrastructures in the design and implementation of e-learning environments [In Persian]. J Manage Plann Educ Sys. 2014;6(10):27-47. 
Table 3. The Main and Secondary Themes of E-Learning in Iranian institutes of Higher Education

\begin{tabular}{|c|c|}
\hline Main Themes & Secondary Themes \\
\hline \multicolumn{2}{|l|}{ Individual characteristics of the learner } \\
\hline Slad (43) & Proportion of the learner's aims and needs \\
\hline Baseri et al. (11) & Creating a positive attitude towards E-learning \\
\hline Elahi et al. (25) & Developing IT skills \\
\hline Schecter (44) & Strengthening confidence and responsibility \\
\hline Yaghobi (27) & Strengthening virtual capability \\
\hline Lee et al. (45) & Considering the speed of learning relative to \\
\hline Ribl and Bali (46) & individual needs \\
\hline \multicolumn{2}{|l|}{ Mirzabaigi (39) } \\
\hline \multicolumn{2}{|l|}{ Educational content } \\
\hline Khan (19) & Information and content updates \\
\hline Yaghobi et al. (27) & Quality of information and content \\
\hline Elahi et al. (25) & A need assessment before starting the course \\
\hline Baseri et al. (11) & Using suitable software programs and organizing the content \\
\hline \multicolumn{2}{|l|}{ Selim (17) } \\
\hline \multicolumn{2}{|l|}{ Model of learning quality (14) } \\
\hline \multicolumn{2}{|l|}{ Helm model (13) } \\
\hline \multicolumn{2}{|l|}{ Mosavi et al. (24) } \\
\hline \multicolumn{2}{|l|}{ Yolf (16) } \\
\hline \multicolumn{2}{|l|}{ Odunaike et al. (9) } \\
\hline \multicolumn{2}{|l|}{ Baghery Majd (20) } \\
\hline \multicolumn{2}{|l|}{ Educational media } \\
\hline Elahi et al. (25) & Accessibility of E-learning systems and easy access to content \\
\hline Baghery Majd (20) & Ability to communicate and get feedback about the sessions \\
\hline Slad (43) & Security of the E-learning system \\
\hline Porter (47) & Multimedia E-learning systems (in form of text, sound, picture, and movie) \\
\hline \multicolumn{2}{|l|}{ Moallem (48) } \\
\hline \multicolumn{2}{|l|}{ Hansen (49) } \\
\hline \multicolumn{2}{|l|}{ Interaction } \\
\hline Selim (17) & Interaction between university teachers and students \\
\hline McMurdo, Anderson, Cook, and Atashk's model & Interaction among learners \\
\hline Learning quality model (14) & Interaction among university teachers \\
\hline Virtual Training Center of Illinois University (15) & Interaction between the content and content \\
\hline Ibrahimzadeh (50) & Interaction between the content and the student \\
\hline \multicolumn{2}{|l|}{ Grison and Anderson (51) } \\
\hline Measurement method & Assessment based on critical thinking and problem-solving \\
\hline \multicolumn{2}{|l|}{ Masoumi (5) } \\
\hline \multicolumn{2}{|l|}{ Moallem (52) } \\
\hline Pettenati et al. (53) & \\
\hline
\end{tabular}




\begin{tabular}{|c|c|}
\hline \multicolumn{2}{|l|}{ Presentation (oral) } \\
\hline Rasgarpour and Gorgizade (23) & Specifying the teacher's plan and using chat environments and online classes \\
\hline Masoumi (5) & Using the forum as a tool \\
\hline \multicolumn{2}{|l|}{ Technology infrastructure } \\
\hline Govindasamy (54) & Internet speed and band width \\
\hline Sung et al. (55) & Access to the Internet \\
\hline Basiri et al. (11) & Access to computers \\
\hline \multicolumn{2}{|l|}{ Elahi et al. (25) } \\
\hline \multicolumn{2}{|l|}{ Yolf (16) } \\
\hline \multicolumn{2}{|l|}{ Mosavi et al. (24) } \\
\hline \multicolumn{2}{|l|}{ Learning quality model (14) } \\
\hline \multicolumn{2}{|c|}{ Cultural and educational infrastructures } \\
\hline Sfard (56) & $\begin{array}{l}\text { Educational approach, Learning environment based on exploration and participation in the } \\
\text { process of learning and teaching }\end{array}$ \\
\hline Reeves (57) & Experimental importance, Electronic educational environment based on personal experience \\
\hline Henderson (58) & Teacher's role, Teacher as the facilitator of learning activities for the students \\
\hline \multirow[t]{5}{*}{ Masoumi (59) } & Value of errors, Learning through experience \\
\hline & Motivation, Creating a learning environment for increasing motivation among learners \\
\hline & Individual differences, Attention to different learning styles of the learners \\
\hline & Learning control, Flexible education and selection of the learning path by the learner \\
\hline & Cooperative learning in the learning environment and collaborative learning \\
\hline
\end{tabular}

